\title{
The experience of undergoing a Teaching Internship apply- ing active methodologies
}

\author{
A experiência de realizar um Estágio Docência aplicando metodologias ativas \\ La experiencia de realizar una Práctica de Docencia aplicando metodologías activas
}

\author{
Marilene Loewen Wall ${ }^{1}$, Marta Lenise do Prado $^{2}$, Telma Elisa Carraro ${ }^{2}$
}

\begin{abstract}
Knowledge has become our society's main resource. It is organized around the areas of application, where teaching institutions are expected to use it in actions focused on society and building the knowledge linked with reality. This article presents the report of a Teaching Internship experience in a Nursing undergraduate course at a federal educational institution, where the teaching-learning process happened through an innovative pedagogy with the application of active methodologies. By sharing this experience, we present a brief and critical reflection in the light of the consulted literature. Classroom theory needs to be articulated with reality, with practice, trying to explain it, aiming at understanding it, so that interventions and changes can be made, turning our students into citizens and subjects.
\end{abstract}

Keywords: Education, nursing; Education/methods; Faculty, nursing

\section{RESUMO}

O conhecimento tornou-se o recurso principal da nossa sociedade e está organizado em torno das áreas de aplicação, esperando-se que as instituições de ensino utilizem-no em ações realizadas na sociedade e construindo o conhecimento vinculado à realidade. Este artigo traz o relato da experiência de um Estágio Docência no Curso de Graduação em Enfermagem de uma instituição federal de ensino, onde o processo de ensino-aprendizagem aconteceu utilizando-se uma pedagogia inovadora, aplicando metodologias ativas. Ao compartilhar essa experiência, trazemos uma breve reflexão e crítica à luz da bibliografia consultada. Percebe-se que a teoria da sala de aula precisa estar articulada à realidade, à prática, tentando explicá-la, procurando compreendê-la, para assim intervir e mudá-la, tornando nosso aluno sujeito e cidadão.. Descritores: Educação em enfermagem; Educação/métodos; Docente de enfermagem

\section{RESUMEN}

El conocimiento se convirtió en el recurso principal de nuestra sociedad y está organizado en torno a las áreas de aplicación, esperándose que las instituciones de enseñanza lo utilicen en acciones realizadas en la sociedad y construyendo el conocimiento vinculado a la realidad. Este artículo presenta el relato de la experiencia de una Práctica de Docencia en el Curso de Pregrado en Enfermería de una institución federal de enseñanza, donde el proceso de enseñanza-aprendizaje sucedió utilizándose una pedagogía innovadora, aplicando metodologías activas. Al compartir esta experiencia, traemos una breve reflexión y crítica a la luz de la bibliografía consultada. Se percibe que la teoría impartida en la sala de clase precisa estar articulada a la realidad, a la práctica, tratando de explicarla, procurando comprenderla, para así intervenir y cambiarla, tornando a nuestro alumno sujeto y ciudadano.

Descriptores: Educación en enfermería; Educación/métodos; Docente de enfermería

\footnotetext{
${ }^{1}$ Graduate student, Professor at the Nursing Department of Universidade Federal do Paraná - UFPR - Curitiba (PR), Brazil.

2 Ph.D., Professor of the Graduate Nursing Program at Universidade Federal de Santa Catarina - UFSC - Florianópolis (SC), Brazil.
} 


\section{INTRODUCTION}

We have been living in a global society where knowledge has become an important resource, because everything is in constant evolution and transformation. We professionals are expected to be capable of analyzing complex situations, quickly and consciously choosing strategies adapted to ethical goals and demands, choosing among a wide range of knowledge topics, techniques and instruments, and adapting our actions and results in a critical way.

In addition, we can also say that respecting people, knowing and dominating emotions and teamwork are necessary in the quest for excellence in the profession, so that we can deal with the changes successfully. The quick growth of knowledge and information demands professionals who are capable of quickly learning new contents, skills and strategies that enable them to acquire new knowledge and forms of accessing $\mathrm{it}^{(1)}$.

As a nurse acting in teaching, I see that constant investments in knowledge and learning are needed. Therefore, I entered a doctoral program, part of the Graduate Nursing Program at Universidade Federal de Santa Catarina ${ }^{(2)}$.

During the Doctoral Nursing Course, I had the opportunity of taking a Teaching Internship, a curricular activity for stricto sensu graduate students, defined as the participation of the student in teaching activities at the institution under the supervision of an advisor. This internship happened in 2006 in the Fundamentals of Professional Healthcare course, part of the undergraduate Nursing curriculum at Universidade Federal de Santa Catarina - UFSC, in its third year

The teaching-learning process happens based on the utilization of active methodologies, in which the students are the protagonists of their learning process and the professors take the role of mediators/ facilitators. The implementation of active methodologies in undergraduate courses implies multiple challenges, from structural (academic and administrative organization of the institutions and courses) to pedagogical conceptions (beliefs, values and ways of doing) of students and teachers.

Thus, this article aims to present a critical and reflexive report on the experience of implementing active methodologies in a course that was part of an undergraduate Nursing program at a federal educational institution, by understanding that it meant experiencing changes, confrontation of models and expectations, facing conflicts and accepting challenges.

\section{THE EVERYDAY ROUTINE OF TEACHING AND LEARNING}

First day in class. Meeting again, with happiness, expectations, novelty and anxiety for both teachers and students. The members of a large group were introduced through group dynamics. The goals, methodology, course contents, teaching plans and the work proposal for the semester were also introduced. The students were divided in three smaller groups, each under the responsibility of a tutor and two facilitators.

Next, part of the teaching-learning activities, such as theoretical and practical classes, were developed in small groups. We held meetings with the large group every third week to present case studies and the syntheses performed, lectures with specialists and also formal evaluations and discussions, with criticism and suggestions about their progress. In the smaller group, we set the rules and norms of conduct and made individual and collective commitments. The students also chose words like: growth, strength, ease, vitality, perseverance, renewal, joy and collaboration, which would be pillars for the semester in college.

Adult education in universities assumes the use of active teaching-learning methodologies, proposing concrete challenges the students had to overcome, allowing them to be subjects in the construction of knowledge. The professor has to prepare the field to promote the students' activities, i.e. incite them to trigger their actions ${ }^{(3)}$. This pedagogical proposal has a humanistic and socio-interactionist approach, predominantly focusing on the subject, where the professor is a facilitator of learning, creating situations for the students to learn the content, which consists in the experiences they rebuild ${ }^{(4)}$.

Another characteristic of this innovative pedagogical model is learning by doing, where knowledge production is linked to real-life scenarios. Therefore, our students used the Medical and Surgical Clinical Units of a University Hospital to learn, in practice, the fundamentals for professional Nursing care, returning to the classroom afterwards, where they presented an inpatient's first case, in groups of two. The tutoring teacher conducted the presentation and discussion of the cases so that the students could identify the condition of this patient, and which types of nursing healthcare were necessary. It was emphasized that Nursing care is for people, not for diseases.

Based on this information, the students created a fictitious case, and we chose the first nursing care to be studied. It is evident that thedynamics of the teachinglearning process happened by means of action-reflectionaction, because the students had practical classes in the Nursing Practice Laboratory in parallel with theoretical studies, returning to the Hospital to apply their theoretical knowledge and experienced the daily routine of Nursing. In this experience, the students observed situations that went well beyond the learning issues listed in the 
classroom, facing ethical issues, biosafety situations, multiprofessional relationships, labor issues and institutional and professional power relations. The questions, arising in the student's routine at the hospital institution, were taken to class and submitted to debate. Further theoretical studies were promoted through reading.

The use of active methodologies requires a flexible and articulated posture from the professor, since those are tools to reach active, critical subjects, able to transform themselves and their context. Thus, the teaching techniques used should permit the representation of the group of questions, providing the manifestation and taking into account the learning time of each student. By itself, the technique will depend on whatever seems more adequate and useful for the concrete learning situation, be it working with larger or smaller groups, dramatization, demonstrations, movie, integrated panels, experiencing and creative games, among others ${ }^{(5)}$.

Regarding the study dynamics, the group's suggestion was that everybody would study the subject integrally, either individually or in groups, taking notes, discussing and sharing them in the classroom, as well as texts retrieved from journals, books or websites. This study dynamics involved the development of skills for searching, selection and critical evaluation of data and information available in databases.

The meetings, i.e. theoretical classes, would always start with a conversation in a large circle, where the students talked about their studying process. They shared the way they studied, where they searched information and how this experience had been. It was observed that they would always study in groups of two or three, sought a lot of data in sites and journals, besides the books available at the university library. This strategy aimed to develop the students' initiative and autonomy, and also to promote the instrumentalization of adequate and reliable sources of information gathering. It was also an exercise of criticism on the produced knowledge by instructing the students about its acquisition.

An agreement made at the beginning of the semester was that everybody in this circle would speak. At first, some shy students had difficulties to speak in public, but this skill was also put in practice, since communication is considered a basic instrument for caring, with the function of informing, persuading, teaching and discussing, besides promoting relations among people to seek solutions ${ }^{(6)}$.

Each meeting was started with a warm-up situation, i.e. strategies used to encourage, orient, aid in the interaction, focus attention and awaken the group for the educational process" (7). This warm-up was followed by the class theme discussion, while searching for answers for the learning issues obtained from the construction of the case study during the first day of class. Certainly, the group brought other questions besides those initially elaborated, since the search for answers incites other questions, encouraging research and richly contributing to the teaching-learning process.

In this new position, the professor understands that he is not the one who "places knowledge in the students" minds", but the subject who builds knowledge, based on the social relation mediated by reality. The professor is responsible for inciting the students to think about the issue of learning, making situations or elements available for the elaboration of answers to the problems obtained and interacting with the student, favoring the "reconstruction of the existing relations in the object of knowledge"(3).

Meetings with the larger group of students and teachers were held regularly, where the synthesis of the learning issues, made by the subgroups, was presented to the others. This usually happened through dramatizations. Besides these group discussions, we had lectures with professors (specialists on specific topics) and counted on the participation of professionals who contributed to the contents discussed, with their professional experience and testimonies from their practice.

Multiple instruments were used for the evaluation of this teaching-learning process, so that the many competencies expected from the students during the course could be considered. Therefore, the students' evaluation process happened through formal written tests, practical tests done while developing activities at the Nursing Laboratory when the students would execute the techniques learned, evaluations about their hospital performance and also their portfolio.

The portfolio is a project created by the students themselves, using different languages that demonstrate their professional education, "in a constant movement of self-reflection that translates the learning act itself"(8). It is "a collection of the projects executed by the students, which allows them to analyze, evaluate, execute and present productions resulting from activities developed in a given period". As such, activities like text summaries, syntheses of studied themes, visit reports, projects and research reports, written tests, notes on experiments, or any tasks performed by the students are collected in a binder, album or notebook ${ }^{(9)}$. The construction of the portfolio by our students allowed the professors and the students themselves to evaluate and reflect about the teaching-learning process, making way for the introduction of the necessary changes, so that everybody could achieve the expected competencies.

The use of active learning methodologies implies a 
formative and additive evaluation. The formative evaluation looks at the process and allows the professor to perceive difficulties that interfere in the students' learning, enabling a periodical and continual review of the students' progress, as an interactive process that can guide the proposed objectives ${ }^{(10)}$.

\section{REFLECTING ABOUT THIS PRACTICE}

It is evident that the more important knowledge becomes for society, the more important diversity, flexibility and excellence will be in whatever we do. Like in other sciences, in Nursing, we also face the need to make decisions about the ways of knowledge and their consequences. However, to do so, we need people capable of producing new knowledge that can be applied for the good of society.

The educational actions we developed and the methodology we used can aid our students to break free from values and beliefs that held them back, impeding them from developing as human beings. It is worth noting that the educational action and the teaching methods we used can have characteristics that maintain our students in a situation of dependence, where they are manipulated and keep submitting themselves to unfair norms and rules.

I believe the collective experience with the undergraduate students in this course demonstrates the willingness and the effort in seeking and applying a theoretical-methodological reference that will help the students to adequate themselves to the transformations of healthcare reality in Brazil. We experience and are aware that information, technologies and knowledge are increasing and changing fast, one of the reasons why our students need to learn to seek them constantly, as well as to develop attitudes and skills that will prepare them to live in this society, performing their professional duties with competence.

We understand that the educational practice also has a political characteristic, being responsible for the preparation and training of citizens. Therefore, "we should reinforce the formative model in pedagogical practice, the model that promotes a better harmony

\section{REFERENCES}

1. Barros SMO, Bork AMT, Farah OGD. A experiência pedagógica para a formação dos futuros profissionais de enfermagem. In: Bork AMT. Enfermagem de excelência: da visão à ação. Rio de Janeiro: Guanabara Koogan; 2003. p. 167-74.

2. Universidade Federal de Santa Catarina. Regimento Interno do Programa de Pós-Graduação Stricto Sensu em Enfermagem da Universidade Federal de Santa Catarina. Florianópolis: UFSC; 2000.

3. Vasconcellos CS. Construção do conhecimento em sala de between thinking and feelings, and between the development of the capacity of abstraction and of several personality aspects"(11). Our commitment, as teachers, goes beyond professional education, also lying in the preparation of ethical subjects who are committed to mankind. To meet these objectives, reality and daily routines should enter the classroom, determining the themes and pace of the learning process. The professors should recognize the pedagogic intention orienting their actions and valuate the students' protagonism, without disregarding their interests and curiosities, and provide, at the same time, means for attaining the discipline expected in the course.

Processes of change always entail difficulties. That is why it was important to observe how the group of teachers was watchful to deal with emerging conflicts. We can say that we invested in critical and systematic reflections, as well as in the maintenance of collective spaces of discussion, by means of meetings, workshops, reading references, lectures with specialists and constant exchanging of ideas, so that the group of teachers could incorporate and comply with the pedagogic reference. This process of change has not been concluded, but we noticed that the students showed initiative and commitment with the learning process itself, developed critical perspectives and noticed the importance of collective work, aware of their mission as agents of change.

In order to teach, we need to organize ourselves, considering interdisciplinary areas. We need to retrieve information from research studies in order to generate knowledge. We need people who can develop and teach the application of knowledge and information extracted from different courses to obtain even more favorable resources. We can say that the Teaching Internship is a valuable and important activity in the qualification process, and it becomes even more significant when one can learn how to contribute to the education of "workers with knowledge, who are not simply based on their physical capacity to perform work, but on their capacity in the form of knowledge [...], prepared to act on their own initiative due to their knowledge, and prepared to make decisions"(12). aula. 13a ed. São Paulo: Libertad; 2002

4. Mizukami MGN. Ensino: as abordagens do processo. São Paulo: Editora Pedagógica e Universitária; c1986.

5. Rede Unida. A construção de modelos inovadores de ensino-aprendizagem: as lições aprendidas pela Rede Unida. Divulgação em Saúde para Debate [Internet] 2007 [citado 2007 Ago 20] Disponível em: http:// www.redeunida.org.br/producao/div_licoes.asp.

6. Cianciarullo TI. Instrumentos básicos para o cuidar: um desafio para a qualidade de assistência. São Paulo: Atheneu; 1996. 
7. Wall ML. Metodologia da assistência: um elo entre a enfermeira e a mulher-mãe [dissertação]. Curitiba: Universidade Federal do Paraná; 2000.

8. Gusman AB, Rezende EMM, Loyola MES, Abreu N. Portfólio: conceito e produção [Internet] 2007 [citado 2007 Ago 6] Disponível em: www.uniube.br/institucional/ biblioteca/arquivos/portfolio biblioteca uniube.pdf

9. Alvarenga GM. Portfólio o que é e a que serve? Olho
Mágico. 2001; 8(1):18-21.

10. Sakai MH, Takahashi OC, Kikuchi EM, Ito K. O sentido do processo de avaliação nas metodologias ativas de aprendizagem. Olho Mágico. 2001; 8(1):5-7.

11. Reibnitz K, Prado ML. Inovação e educação em Enfermagem. Florianópolis: Cidade Futura; 2006.

12. Drucker PF. O melhor de Peter Drucker. A sociedade. São Paulo: Nobel; 2001. 